\title{
Prevalence of ESBL/AmpC genes and specific clones among the third- generation cephalosporin-resistant Enterobacteriaceae from canine and feline clinical specimens in Japan
}

\author{
Yoshihiko Maeyama $^{\mathrm{a}, \mathrm{b}, 1}$, Yui Taniguchi ${ }^{\mathrm{a}, 1}$, Wataru Hayashi ${ }^{\mathrm{a}, 1}$, Yusuke Ohsaki ${ }^{\mathrm{a}}$, Shunsuke Osaka ${ }^{\mathrm{a}}$, \\ Shota Koide ${ }^{\mathrm{a}}$, Kiyoko Tamai ${ }^{\mathrm{b}}$, Yukiko Nagano ${ }^{\mathrm{c}}$, Yoshichika Arakawa ${ }^{\mathrm{c}}$, Noriyuki Nagano, ${ }^{\mathrm{a}, *}$

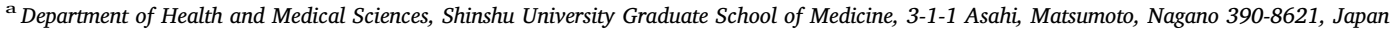 \\ b Miroku Medical Laboratory Inc., 659-2 Innai, Saku, Nagano 384-2201 Japan \\ ${ }^{\mathrm{c}}$ Department of Bacteriology, Nagoya University Graduate School of Medicine, 65 Tsurumai-cho, Showa-ku, Nagoya, Aichi 466-8550, Japan
}

\section{A R T I C L E I N F O}

\section{Keywords:}

bla $a_{\mathrm{CTX}-\mathrm{M}-27}$

ESBL

B2-O25-ST131-H30R

E. coli

K. pneumoniae

Companion animals

\begin{abstract}
A B S T R A C T
In recent years, besides the widespread occurrence of extended-spectrum $\beta$-lactamase (ESBL)- and/or plasmidmediated AmpC (pAmpC)-producing Enterobacteriaceae in both healthcare and community settings of humans, the third-generation cephalosporin (3GC)-resistant microbes have also been reported from companion animals worldwide. Here, we characterized ESBL- and/or pAmpC-producing Enterobacteriaceae clinical isolates from companion animals. Among the 487 clinical isolates mainly from urine of dogs and cats between May and September 2016, 104 non-repetitive isolates were resistant to the 3GC, and they consisted of 81 of 381 (21.3\%) Escherichia coli, 21 of 50 (42.0\%) Klebsiella pneumoniae, and 2 of 56 (3.6\%) Proteus mirabilis isolates. In the 81 E. coli, the predominant bla genes were bla $a_{\mathrm{CTX}-\mathrm{M}-27}$ and $b l a_{\mathrm{CMY}-2}\left(\mathrm{n}=15\right.$ each), followed by $b l a_{\mathrm{CTX}-\mathrm{M}-15}(\mathrm{n}=14)$, bla $_{\mathrm{CTX}-\mathrm{M}-14}(\mathrm{n}=10)$, and bla $a_{\mathrm{CTX}-\mathrm{M}-55}(\mathrm{n}=5)$. In $21 \mathrm{~K}$. pneumoniae, 10 bla gene types including bla $a_{\mathrm{CTX}-\mathrm{M}-15}$

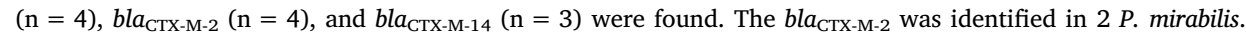
Twenty-four of the $42 \mathrm{E}$. coli belonging to phylogroup B2 were O25b-ST131 clone, mostly associated with uropathogenic E. coli pathotype, and 22 isolates of this clone were identified as specific H30R subclone. High prevalence of the $b l a_{\mathrm{CTX}-\mathrm{M}-27}$-harboring isolates were noted among the $H 30 \mathrm{R} /$ non-Rx lineage $(13 / 19,68.4 \%)$ $(p<0.05)$. The genetic environment of $b l a_{\mathrm{CTX}-\mathrm{M}-27}$ of most isolates of this lineage was identical to that of human isolates, but unique flanking genetic structures were also identified. Newly emerging virulent lineage B2non-O25b-ST1193 was also confirmed in 5 isolates. The fosA3 and/or armA genes were detected in $E$. coli and $K$. pneumoniae isolates. These data suggest that companion animals serve as a potential reservoir of antimicrobial resistant $E$. coli and $K$. pneumoniae. This also has considerable veterinary importance, since urinary tract infections are an important disease causing therapeutic challenges worldwide.
\end{abstract}

\section{Introduction}

Over the last two decades, extended-spectrum- $\beta$-lactamase (ESBL)and plasmid-mediated $\mathrm{AmpC}(\mathrm{pAmpC})$-producing Enterobacteriaceae exhibiting resistance to the third-generation cephalosporins (3GC) have been increasingly isolated in humans. In recent years, besides the widespread occurrence of ESBL- and/or pAmpC-producing Enterobacteriaceae in both healthcare and community settings of humans, the 3GC-resistant microbes have also been reported from food animals, food products, companion animals, and environmental sources worldwide (Bevan et al., 2017).
Among the pAmpC $\beta$-lactamase genes, particularly bla $a_{\mathrm{CMY}-2}$ and bla $a_{\mathrm{DHA}-1}$ are the most common in Escherichia coli and Klebsiella pneumoniae, respectively, of human and companion animal isolates (Li et al., 2008; Wohlwend et al., 2015; Harada et al., 2016). In particular, frequency of bla $a_{\mathrm{CMY}-2}$ in $E$. coli isolates from companion animal has been reported to be significantly higher than in those from human (Bortolaia et al., 2014).

Nowadays, CTX-M-15 and CTX-M-14 are the most common types of ESBLs among human isolates, though CTX-M-14 has mainly been reported in Japan and other Asian countries (Zhao and Hu, 2013). A pandemic-specific O25b-ST131 clone with multi-resistance and a high

\footnotetext{
* Corresponding author.

E-mail address: naganon@shinshu-u.ac.jp (N. Nagano).

${ }^{1}$ These authors contributed equally to this work.
} 
virulence potential is largely associated with the global increase of these ESBL producers. The $b{ }_{\text {CTX-M-15 }}$ gene is most closely related with this clone, however, bla $a_{\mathrm{CTX}-\mathrm{M}-14}$ was also reported in Japan, Canada, and Spain (Suzuki et al., 2009; Peirano et al., 2010; Dahbi et al., 2013). The O25b-ST131 clone harboring bla $a_{\mathrm{CTX-M-15}}$ or bla $a_{\mathrm{CTX}-\mathrm{M}-14}$ has also been confirmed among companion animals in many countries (Ewers et al., 2010; Harada et al., 2012; Kawamura et al., 2017). Transmission of the $E$. coli ST131 clone among family members and companion animals has been documented, increasing the risk in human of causing severe infections difficult to be treated (Johnson et al., 2009). The bla $_{\mathrm{CTX-M-27}}$, a single-nucleotide variant of bla $_{\mathrm{CTX-M-14}}$ has been increasingly identified among the isolates from human and companion animals in Asian countries including Japan, European countries, and the US (Harada et al., 2012; Matsumura et al., 2015; Bevan et al., 2017; Kawamura et al., 2017).

In Japan, strict regulation of antimicrobial usage in food animals has been executed by the Government. However, little attention has so far been paid to the use of antimicrobials in companion animals, which was left to the prescription of individual veterinarian. This study was aimed to investigate the presence of ESBL and/or pAmpC genes among the 3GC-resistant Enterobacteriaceae derived from companion animals for better understanding the dissemination dynamics of not only the antimicrobial resistance genes, but also their host bacterial clones. The findings obtained would be useful to assess the possible circulation of those resistance genes and bacterial clones across human and companion animals.

\section{Materials and methods}

\subsection{Bacterial isolates}

During May-September 2016, bacterial isolates were recovered from specimen of companion animals in clinical settings and hospitals throughout Japan. Most of the samples were urine, but also some from other clinical infections were investigated. They were identified using NegCombo BPC1J panel and Microscan WalkAway plus system according to the manufacturer's instructions (Beckman Coulter, Inc, Tokyo, Japan). For some E. coli isolates, the identification was confirmed by MALDI-TOF MS assay using $\geq 2.000$ score cut-offs for species-level identification as recommended by the manufacturer (Bruker Daltonics, Bremen, Germany). A total of $381 \mathrm{E}$. coli isolates including 296 and 85 of canine and feline origin, respectively, $50 \mathrm{~K}$. pneumoniae isolates including 42 and 8 of canine and feline origin, respectively, and 56 Proteus mirabilis isolates including 53 and 3 of canine and feline origin, respectively, were subjected to the study.

\subsection{Antimicrobial susceptibility testing}

MICs for the isolates were determined by the CLSI broth microdilution method according to CLSI document M07-A10 (Clinical and Laboratory Standards Institute (CLSI, 2015) using the same panel and system described for bacterial identification, and the results were interpreted using CLSI M100-S27 standard (Clinical and Laboratory Standards Institute (CLSI, 2017) for human pathogens except for the interpretation of MICs of colistin ( $\leq 2$ and $>2 \mathrm{mg} / \mathrm{L}$ for colistin susceptible and resistant, respectively) followed by the EUCAST standard (European Committee on Antimicrobial Susceptibility Testing (EUCAST, 2017).

For the 3GC-resistant isolates, ESBL and/or AmpC production was confirmed by MADISCS ID ${ }^{\mathrm{TM}}$ ESBL and AmpC Detection Discs (Kanto Chemical Co., Inc., Tokyo, Japan).

\subsection{PCR detection and sequencing of ESBL and pAmpC genes}

ESBL genes $b l a_{\mathrm{TEM}}$ and $b l a_{\mathrm{SHV}}$ types, and $b l a_{\mathrm{CTX}-\mathrm{M}-1}, b l a_{\mathrm{CTX}-\mathrm{M}-2}$, $b l a_{\mathrm{CTX}-\mathrm{M}-9}$, and $b l a_{\mathrm{CTX}-\mathrm{M}-8}$ groups were sought by PCR as described previously (Nagano et al., 2009). Screening of pAmpC gene groups, ACC, FOX, MOX, DHA, CIT, and EBC, was performed by multiplex PCR (Perez-Perez and Hanson, 2002).

The nucleotide sequence of full-length bla gene was determined by direct sequencing of PCR products obtained using the primer sets listed in Supplementary Table S1. Briefly, PCR amplicons derived from each bla gene were purified with a Wizard SV Gel and PCR Clean Up system (Promega, Madison, WI, USA), and sequenced directly on both strands with a BigDye Terminator v1.1 Cycle Sequencing Kit and an ABI 3730xl genetic analyzer (Applied Biosystems, Foster City, CA, USA). The nucleotide and deduced amino acid sequences were analyzed with the BLAST programs (http://www.ncbi.nlm.nih.gov/blast). The ClustalW program (http://www.ebi.ac.uk/clustalw) was used for the analysis of the alignment of the deduced amino acid sequences of $\beta$-lactamases.

The genetic environments surrounding bla $_{\mathrm{CTX}-\mathrm{M}}$ genes were analyzed by PCR mapping and DNA sequencing using primers described in Table S2 with reference to commonly detectable structures (Zhao and Hu, 2013).

\subsection{Detection of plasmidic $16 S$ rRNA methyltransferase and fosfomycin resistance genes}

For aminoglycoside-resistant isolates, plasmid-mediated 16S rRNA methyltransferase genes, $a r m A, r m t B$, and $r m t C$, were detected as described previously (Doi and Arakawa, 2007). For fosfomycin-resistant isolates, plasmid-mediated fosfomycin resistance genes, fos $A 3$ and fosC2, were detected as described previously (Wachino et al., 2010).

\subsection{Classification of EXPEC and UPEC pathotypes}

For all the 3GC-resistant $E$. coli isolates belonging to phylogroup B2, virulence genes responsible for extraintestinal infections were analyzed by multiplex PCR (Johnson et al., 2015). Pathotypes of $E$. coli were presumed to be extraintestinal pathogenic $E$ coli (ExPEC) if positive for $\geq 2$ of 5 markers, including papAH and/or $p a p C, s f a / f o c D E, a f a / d r a B C$, $k p s M$ II and iutA, and to be uropathogenic $E$ coli (UPEC) if positive for $\geq 3$ of 4 markers, including $c h u A$, fyuA, vat and $y f c V$ (Johnson et al., 2015).

\subsection{Molecular typing of E. coli and K. pneumoniae isolates}

Phylogenetic grouping of $E$. coli isolates harboring ESBL and/or pAmpC genes was done by multiplex PCR as described previously (Clermont et al., 2013).

Sequence types (STs) of $K$. pneumoniae isolates harboring ESBL and/ or pAmpC genes were determined by the multi-locus sequencing typing (MLST) method according to the K. pneumoniae MLST website (http:// bigsdb.pasteur.fr/klebsiella/klebsiella.html). For E. coli isolates harboring ESBL and/or pAmpC genes and belonging to the phylogroup B2, STs were determined according to the $E$. coli MLST website (http://mlst. warwick.ac.uk/mlst/mlst/dbs/Ecoli). Additionally, the fimH30 (H30) subclone of ST131 was detected by PCR, and ciprofloxacin-resistant $H 30$ isolates were identified as H30R (Colpan et al., 2013). The H30Rx lineage within H30R subclone was identified by sequencing of PCR product for the detection of SNP-264 as described previously (Price et al., 2013). Distributions of bla $a_{\mathrm{CTX}-\mathrm{M}}$ genes among the H30R and nonH30R subclones of B2-O25b-ST131clone were analyzed using the Chisquare test with Yates correction.

\subsection{E. coli $O$ antigen typing}

ESBL and/or pAmpC gene-positive $E$. coli isolates belonging to serotype $\mathrm{O} 25$ were identified using E. coli antisera (Denka Seiken, Tokyo, Japan) according to the manufacturer's instructions.

Additionally, for E. coli isolates belonging to ST131, the O25b molecular subtype was identified by PCR as described previously 
(Clermont et al., 2008).

\section{Results}

\subsection{Prevalence of ESBL- and/or pAmpC-producing Enterobacteriaceae}

Over the five-month period, a total of 487 Enterobacteriaceae isolates were collected, all of them were susceptible to carbapenems except for some $P$. mirabilis isolates which exhibited reduced susceptibility to carbapenems, as noted in CLSI M100-S27 (Clinical and Laboratory Standards Institute (CLSI, 2017). A total of 104 non-repetitive isolates resistant to the $3 \mathrm{GC}$ were found from canine and feline clinical samples. Of these animals 61 were hospitalized, 20 were not hospitalized and from 23 the status was unknown. Most isolates were recovered from urine specimen (59/104) (Table S3). Of 381 E. coli isolates identified 81 (59 and 22 of canine and feline origin, respectively) were 3GC-resistant (21.3\%). Among $50 \mathrm{~K}$. pneumoniae isolates, 21 (16 and 5 of canine and feline origin, respectively) were 3GC-resistant (42.0\%). For $P$. mirabilis isolates, 2 (canine origin) of $56(3.6 \%)$ were resistant to the 3GC. Phenotypic test revealed that 78 isolates including $59 \mathrm{E}$. coli, $17 \mathrm{~K}$. pneumoniae, and $2 P$. mirabilis were confirmed to be ESBL producers, and 21 isolates including $19 \mathrm{E}$. coli and $2 \mathrm{~K}$. pneumoniae were pAmpC producers. Co-production of both ESBL and pAmpC was detected in $3 E$. coli and $2 \mathrm{~K}$. pneumoniae isolates (Table S3).

\subsection{Antimicrobial susceptibilities of ESBL- and/or pAmpC-producers}

As shown in Supplementary Table S4, the ESBL-producing organisms were resistant to cefpodoxime, ceftazidime, cefotaxime, cefepime, and aztreonam with $\mathrm{MIC}_{90}$ values of $>4 \mathrm{mg} / \mathrm{L},>8 \mathrm{mg} / \mathrm{L},>2 \mathrm{mg}$ / $\mathrm{L},>16 \mathrm{mg} / \mathrm{L}$, and $>8 \mathrm{mg} / \mathrm{L}$, respectively. They also exhibited co-resistance to gentamicin and levofloxacin. The $E$. coli pAmpC producers had the same resistance profiles against those antimicrobials except for cefepime. One isolate of $K$. pneumoniae co-producing ESBL and pAmpC showed resistance to colistin.

\subsection{Molecular characterization of the ESBL and pAmpC genes}

Among the 78 ESBL-producing isolates, the most common types of ESBL genes identified were $b l a_{\mathrm{CTX}-\mathrm{M}-15}(\mathrm{n}=18), b l a_{\mathrm{CTX}-\mathrm{M}-27}(\mathrm{n}=15)$, and $\operatorname{bla}_{\mathrm{CTX}-\mathrm{M}-14}(\mathrm{n}=13)$, which were followed by $\operatorname{bla}_{\mathrm{CTX}-\mathrm{M}-2}(\mathrm{n}=9)$ and $b l a_{\mathrm{CTX}-\mathrm{M}-55}(\mathrm{n}=7)$. A high frequency of $b l a_{\mathrm{CMY}-2}(\mathrm{n}=15)$, followed by $b l a_{\mathrm{DHA}-1}(\mathrm{n}=6)$ was found in the $21 \mathrm{pAmpC}$ producers. The $b l a_{\mathrm{CTX}-\mathrm{M}-15}$, $b l a_{\mathrm{CTX}-\mathrm{M}-27}$, and $b l a_{\mathrm{CTX}-\mathrm{M}-55}$ were also found among co-producers of different ESBL types or those of ESBL and pAmpC (Table S3).

In the $81 \mathrm{E}$. coli isolates resistant to the 3GC, the predominant bla gene was $b l a_{\mathrm{CTX}-\mathrm{M}-27}$ and $b l a_{\mathrm{CMY}-2}(\mathrm{n}=15$ each), and followed by $b l a_{\mathrm{CTX}-\mathrm{M}-15}(\mathrm{n}=14), b l a_{\mathrm{CTX}-\mathrm{M}-14}(\mathrm{n}=10)$, and $b l a_{\mathrm{CTX}-\mathrm{M}-55}(\mathrm{n}=5)$. Coharboring $b l a_{\mathrm{CTX}-\mathrm{M}-55}$ and $b l a_{\mathrm{CMY}-2}, b l a_{\mathrm{CTX}-\mathrm{M}-3}$ and $b l a_{\mathrm{CTX}-\mathrm{M}-27}$, and $b l a_{\mathrm{CTX}-\mathrm{M}-55}$ and bla $_{\mathrm{CTX}-\mathrm{M}-2}$ were found in 3,1 , and 1 , respectively (Tables 1 and 2). Ten bla gene types including $b l a_{\mathrm{CTX}-\mathrm{M}-15}(\mathrm{n}=4), b l a_{\mathrm{CTX}-\mathrm{M}-2}$ $(\mathrm{n}=4)$, and $b l a_{\mathrm{CTX}-\mathrm{M}-14}(\mathrm{n}=3)$ were identified in $21 \mathrm{~K}$. pneumoniae isolates. Co-harboring $b l a_{\mathrm{CTX}-\mathrm{M}-15}$ and $b l a_{\mathrm{CTX}-\mathrm{M}-2}, b l a_{\mathrm{CTX}-\mathrm{M}-15}$ and $b l a_{\mathrm{CMY}-}$ 2, and $b l a_{\mathrm{DHA}-1}$ and $b l a_{\mathrm{SHV}-12}$ were detected in one isolate each (Table 3 ). The $b l a_{\mathrm{CTX}-\mathrm{M}-2}$ was identified in $2 P$. mirabilis isolates.

\subsection{Genetic environment of bla $a_{C T X-M}$}

Among 15 isolates harboring the $b l a_{\mathrm{CTX}-\mathrm{M}-27}, 12$ isolates of $E$. coli B2O25b-ST131-H30R/non-Rx shared flanking genetic structures, IS26$\triangle \mathrm{ISEcp1-bla}$ СTX-M-27- $-\mathrm{IS} 903 D$-IS26, with variation in the length of $\Delta \mathrm{IS} 903 \mathrm{D}$ (338 bp, $340 \mathrm{bp}$ or $391 \mathrm{bp}$ ) (Table 4). The bla $\mathrm{CTX}_{\mathrm{C}-\mathrm{M}-14}$ was associated with the common elements ISEcp1 and $\triangle \mathrm{IS} 903$ or IS903 in all of 13 isolates among diverse clones including E. coli ST131, but with new amino acid substitution $\mathrm{K} 156 \mathrm{~N}$ in tnpA of IS903 in $3 \mathrm{~K}$. pneumoniae ST655 isolates. The $b l a_{\mathrm{CTX}-\mathrm{M}-15}$ had classical flanking genetic structures in 17 including 2 E. coli B2-O25b-ST131-H30R/Rx, that is, it was bracketed upstream and downstream by ISEcp1 and orf 477 , respectively, and upstream by IS26-truncated ISEcp1 in 2 isolates including one E. coli B2-O25b-ST131-H30R/Rx. In one K. pneumoniae ST709 isolate, the $b l a_{\mathrm{CTX}-\mathrm{M}-15}$ gene was preceded uniquely by ISEcp1-IS1ISEcp1. The flanking genetic structures of $b l a_{\mathrm{CTX}-\mathrm{M}-55}$ in 11 isolates was basically the same as that of $b l a_{\mathrm{CTX}-\mathrm{M}-15}$. Namely, ISEcp1-bla $a_{\mathrm{CTX}-\mathrm{M}-55^{-}}$ orf 477 was discovered in 8 isolates with variation in the length of ISEcp1-bla $a_{\mathrm{CTX}-\mathrm{M}-55}$ spacer regions, $45 \mathrm{bp}$ or $48 \mathrm{bp}$. In the remaining 3 isolates, IS26-truncated ISEcp1 was identified upstream of the $b l a_{\mathrm{CTX}-\mathrm{M} \text { - }}$ 55 , and IS26-flanked fosA3 was further located downstream of orf477 in one $E$. coli isolate.

\subsection{Molecular lineage analysis of E. coli isolates}

The 81 E. coli isolates harboring bla genes that showed resistance to the 3GC mainly assigned phylogroup B2 (42 isolates, 51.9\%), followed by phylogroups F (16 isolates, 19.8\%), D (9 isolates, 11.1\%), and B1 (8 isolates, $10.0 \%$ ) as shown in Tables 1 and 2. Phylogroup B2 isolates were comprised of $24 \mathrm{O} 25 \mathrm{~b}$ isolates, where presumed UPEC and ExPEC were $22(91.7 \%)$ and 15 isolates (62.5\%), respectively, and 18 nonO25b isolates, where presumed UPEC and ExPEC were 14 (77.8\%) and 12 isolates $(66.7 \%)$, respectively (Table 1 ). All of those $24 \mathrm{O} 25 \mathrm{~b}$ isolates belonged to the pandemic ESBL-producing E. coli B2-O25b-ST131 clone, though two of them did not agglutinate with the $\mathrm{O} 25$ antiserum. Furthermore, 19 isolates of the 24 B2-O25b-ST131 clone mostly associated with UPEC pathotype were identified as specific B2-O25b-ST131$H 30 \mathrm{R} /$ non-Rx lineage, among the 19 high prevalence of the $b l a_{\text {CTX-м-27- }}$ harboring isolates was found $(13 / 19,68.4 \%)(p<0.05)$. Of 5 bla CTX-M- $^{-}$

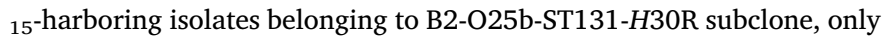
3 were assigned to $H 30 \mathrm{R} / \mathrm{Rx}$ lineage. The STs and bla gene types were diverse among 18 B2-non-O25b isolates, where ST1193 (5/18, 27.8\%) and ST131 (4/18, 22.2\%) were identified (Table 1). The other 9 B2non-O25b isolates were assigned to ST38 (2/18), ST12 (2/18), ST372 (2/18), ST95 (1/18), ST127 (1/18), and ST1262 (1/18). The bla genes were diversely detected among non-O25 isolates belonging to the phylogroups $\mathrm{F}$, which was predominantly detected, D, B1, clade I or II, $\mathrm{A}$, and C (Table 2). Plasmid-mediated fosfomycin-resistance determinant fosA3 gene was detected in an isolate co-harboring bla $_{\mathrm{CTX} \text {-M-55 }}$ plus $b l a_{\mathrm{CMY}-2}$ genes, and a $b l a_{\mathrm{CTX}-\mathrm{M}-27}$-harboring isolate, both of which belonged to the phylogroup $\mathrm{F}$.

\subsection{ST distribution of K. pneumoniae isolates}

The STs of the 21 bla-harboring $K$. pneumoniae isolates showing resistance to the 3GC were classified into 9 types, in which the 7 isolates (33.3\%) were identified to belong to international clone ST15. A bla DHA${ }_{1}$-harboring ST15 isolate had the plasmid-mediated 16S rRNA methylase gene $\operatorname{arm} A$, and a $b l a_{\mathrm{DHA}-1^{-}}$and $b l a_{\mathrm{SHV}-12^{-}}$-harboring ST37 isolate had $\operatorname{arm} A$ and fosA3 (Table 3 ).

\section{Discussion}

In Japan, the antimicrobial resistance (AMR) action plan lists companion animals into the subjects in which researches and surveys to countermeasure AMR need to be conducted. Despite sharing their habitation with human, study findings on antimicrobial resistant microbes in companion animals have been limited. Thus, we were prompted to conduct the present study to investigate the prevalence status of ESBL and $\mathrm{pAmpC}$ genes, and ESBL- and $\mathrm{pAmpC}$-producing lineages among 104 3GC-resistant Enterobacteriaceae clinical isolates recovered from canine and feline patients which are particularly in close contact with humans.

The Japan Nosocomial Infections Surveillance (JANIS) data shows a notable increase in the frequency of cefotaxime resistance in $E$. coli and K. pneumoniae human clinical isolates from $12.6 \%$ and $3.3 \%$ in 2014 to 
Table 1

Serotypes, sequence types, and pathotypes among the third-generation cephalosporin-resistant Escherichia coli phylogroup B2 harboring bla genes.

\begin{tabular}{|c|c|c|c|c|c|c|c|c|c|c|}
\hline \multirow[t]{2}{*}{ Phylogroup } & \multirow[t]{2}{*}{ Serotype } & \multirow[t]{2}{*}{$n$} & \multirow[t]{2}{*}{ Sequence type } & \multirow[t]{2}{*}{$n$} & \multirow[t]{2}{*}{ Subclone/ lineage } & \multirow[t]{2}{*}{$n$} & \multirow[t]{2}{*}{ bla genes } & \multirow[t]{2}{*}{$n$} & \multicolumn{2}{|c|}{ Pathotypes ${ }^{a}$} \\
\hline & & & & & & & & & UPEC & EXPEC \\
\hline \multirow[t]{23}{*}{ B2 } & $\mathrm{O} 25 \mathrm{~b}$ & 24 & ST131 & 24 & H30R/ non-Rx & 19 & CTX-M-27 & $12^{\mathrm{b}, *}$ & 12 & 10 \\
\hline & & & & & & & CTX-M-3 + CTX-M-27 & $1^{*}$ & 1 & 0 \\
\hline & & & & & & & CTX-M-15 & 2 & 2 & 1 \\
\hline & & & & & & & CTX-M-14 & 1 & 0 & 1 \\
\hline & & & & & & & CTX-M-3 & 3 & 2 & 0 \\
\hline & & & & & $H 30 \mathrm{R} / \mathrm{Rx}$ & 3 & CTX-M-15 & $3^{\mathrm{b}}$ & 3 & 3 \\
\hline & & & & & non- $H 30$ & 2 & CTX-M-14 & 1 & 1 & 0 \\
\hline & & & & & & & CMY-2 & 1 & 1 & 0 \\
\hline & non-O25b & 18 & ST131 & 4 & non- $H 30$ & 4 & СТХ-M-15 & 1 & 0 & 1 \\
\hline & & & & & & & CTX-M-14 & 2 & 0 & 0 \\
\hline & & & & & & & CTX-M-2 & 1 & 1 & 0 \\
\hline & & & ST1193 & 5 & NA & & CTX-M-27 & 2 & 2 & 2 \\
\hline & & & & & & & CTX-M-15 & 1 & 1 & 1 \\
\hline & & & & & & & CMY-2 & 1 & 1 & 1 \\
\hline & & & & & & & CTX-M-55 & 1 & 1 & 1 \\
\hline & & & ST38 & 2 & NA & & CTX-M-15 & 1 & 1 & 1 \\
\hline & & & & & & & CMY-2 & 1 & 1 & 0 \\
\hline & & & ST12 & 2 & NA & & CMY-2 & 1 & 1 & 1 \\
\hline & & & & & & & DHA-1 & 1 & 1 & 1 \\
\hline & & & ST372 & 2 & NA & & CMY-2 & 2 & 2 & 1 \\
\hline & & & ST95 & 1 & NA & & CTХ-M-55 & 1 & 1 & 0 \\
\hline & & & ST127 & 1 & NA & & CTX-M-15 & 1 & 0 & 1 \\
\hline & & & ST1262 & 1 & NA & & СТХ-M-14 & 1 & 1 & 1 \\
\hline
\end{tabular}

ExPEC, extraintestinal pathogenic $E$ coli; UPEC, uropathogenic $E$ coli; NA, not analyzed.

${ }^{a}$ Pathotypes of ExPEC (if positive for $\geq 2$ of 5 markers, including papAH and/or papC, sfa/focDE, afa/draBC, $k p s M$ II and iutA) and UPEC (if positive for $\geq 3$ of 4 markers, including chuA, fyuA, vat and $y f c V$ ) were determined (Johnson et al., 2015).

${ }^{\mathrm{b}}$ Including one which did not cause bacterial agglutination with $E$. coli $\mathrm{O} 25$ antiserum, but was positive for the O25b molecular subtype.

* Significant association was observed between $b a_{\mathrm{CTX}-\mathrm{M}-27}$ and a specific lineage, B2-O25b-ST131-H30R/non-Rx $(p<0.05)$.

$24.5 \%$ and $8.0 \%$ in 2015 , respectively. For the clinical isolates from companion animals in 2016 in this study, the resistance rate of $E$. coli isolates to cefotaxime was found to be $21.3 \%$, which was closely to the results reported in the JANIS as well as in the previous studies (Kawamura et al., 2017). However, in K. pneumoniae, the resistance rate to cefotaxime of $42.0 \%$ from canine and feline clinical isolates was far higher than those from JANIS data on human clinical isolates. A similar rate of cefotaxime resistance $(34.0 \%)$ in $K$. pneumoniae isolates from companion animals has been reported in Japan, whereas resistance rate to 3GC has been $21.4 \%$ even in Italy (Donati et al., 2014; Harada et al., 2016). Thus, companion animals as a potential reservoir of antimicrobial resistant $K$. pneumoniae should be taken into account in Japan.

CTX-M-15-producing $K$. pneumoniae international clone ST15 is currently the most widespread clone among human and companion animals, involved in nosocomial infections in both (Haenni et al., 2012). Our results showed diversity in STs among $K$. pneumoniae isolates harboring ESBL and/or pAmpC genes, though ST15 were detected in relatively lower frequency among the isolates. The finding is inconsistent with previous study, where the predominance of CTX-M-15producing $K$. pneumoniae ST15 clone has been noted in companion animals (Harada et al., 2016). The bla $a_{\mathrm{CTX}-\mathrm{M}-27}$, a major ESBL gene in $E$. coli in our present study was not identified among the $21 \mathrm{~K}$. pneumoniae isolates.

In $E$. coli isolates, their ESBL gene types were diverse, whereas $b l a_{\mathrm{CMY}-2}$ gene constituted a majority of the $\mathrm{pAmpC}$ genes, followed by $b l a_{\text {DHA-1 }}$. Frequency of main single ESBL or pAmpC genes in the 3GCresistant $E$. coli was $15(18.8 \%)$ for $b l a_{\mathrm{CTX}-\mathrm{M}-27}$ and $b l a_{\mathrm{CMY}-2}$ each, 14

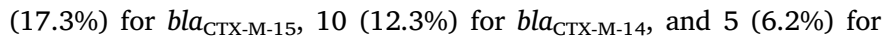

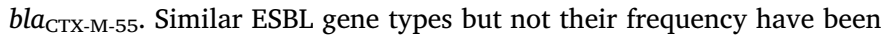
reported in previous studies on companion animals and human (Harada et al., 2012; Matsumura et al., 2015; Kawamura et al., 2017). High frequency of bla $a_{\mathrm{CMY}-2}$ has also been found among the 3GC-resistant $E$. coli from companion animals in Japan (Okubo et al., 2014).

Though aminoglycosides and fosfomycin are important therapeutic options for human infections caused by 3GC-resistant Gram-negative

Table 2

Other phylogroups of the third-generation cephalosporin-resistant Escherichia coli harboring bla genes.

\begin{tabular}{|c|c|c|c|c|c|c|c|c|c|c|c|c|c|c|c|c|}
\hline \multirow{2}{*}{$\begin{array}{l}\text { Phylo- } \\
\text { group }\end{array}$} & \multirow[t]{2}{*}{ Serotype } & \multirow[t]{2}{*}{$n$} & \multicolumn{14}{|c|}{ bla genes } \\
\hline & & & CMY-2 & $\begin{array}{l}\text { CTX- } \\
\text { M-15 }\end{array}$ & $\begin{array}{l}\text { CTX- } \\
\text { M-14 }\end{array}$ & CTX-M-1 & $\begin{array}{l}\text { CTX- } \\
\text { M-55 }\end{array}$ & DHA-1 & $\begin{array}{l}\text { CTX-M- } \\
55+\text { CMY-2 }\end{array}$ & CTX-M-2 & CTX-M-3 & $\begin{array}{l}\text { CTX- } \\
\text { M-24 }\end{array}$ & $\begin{array}{l}\text { CTX- } \\
\text { M-27 }\end{array}$ & $\begin{array}{l}\text { CTX- } \\
\text { M-65 }\end{array}$ & $\begin{array}{l}\text { CTX-M- } \\
55+\text { CTX-M-2 }\end{array}$ & SHV-12 \\
\hline $\mathrm{F}$ & non-O25 & 16 & 3 & 3 & 1 & 2 & 1 & 2 & $1^{\mathrm{a}}$ & & $1^{\mathrm{a}}$ & 1 & 1 & & & \\
\hline $\mathrm{D}$ & & 9 & 3 & 1 & 4 & & 1 & & & & & & & & & \\
\hline B1 & & 8 & 2 & & & & & 1 & 2 & 1 & & & & & 1 & 1 \\
\hline $\begin{array}{l}\text { Clade I } \\
\text { or II }\end{array}$ & & $3^{\mathrm{b}}$ & 1 & 1 & & 1 & & & & & & & & & & \\
\hline A & & 2 & & & & & 1 & & & & & & & 1 & & \\
\hline C & & 1 & & & & & & & & 1 & & & & & & \\
\hline Total & & 39 & 9 & 5 & 5 & 3 & 3 & 3 & 3 & 2 & 1 & 1 & 1 & 1 & 1 & 1 \\
\hline
\end{tabular}

${ }^{a}$ Harboring plasmid-mediated fosfomycin-resistance determinant fos $A 3$.

${ }^{\mathrm{b}}$ Identified as E. coli by MALDI-TOF MS assay. 
Table 3

Sequence types of the third-generation cephalosporin-resistant Klebsiella pneumoniae harboring bla genes.

\begin{tabular}{|c|c|c|c|c|c|c|c|c|c|c|c|}
\hline \multirow[t]{2}{*}{ MLST sequence type } & \multirow[t]{2}{*}{$n$} & \multicolumn{10}{|l|}{ bla gene } \\
\hline & & CTX-M-2 & CTX-M-15 & CTX-M-14 & CTX-M-3 & CTX-M-55 & DHA-1 & CTX-M-15 + CTX-M-2 & CTX-M-15 + CMY-2 & DHA-1 + SHV-12 & SHV-12 \\
\hline ST15 & 7 & 1 & & & & 2 & $2^{\mathrm{a}}$ & & 1 & & $1^{\mathrm{b}}$ \\
\hline ST655 & 3 & & & 3 & & & & & & & \\
\hline ST11 & 2 & 2 & & & & & & & & & \\
\hline ST147 & 2 & & & & 2 & & & & & & \\
\hline ST307 & 2 & & 2 & & & & & & & & \\
\hline ST709 & 2 & 2 & & & & & & 1 & & & \\
\hline ST4 & 1 & & 1 & & & & & & & & \\
\hline ST37 & 1 & & & & & & & & & $1^{\mathrm{c}}$ & \\
\hline ST45 & 1 & & 1 & & & & & & & & \\
\hline Total & 21 & 4 & 4 & 3 & 2 & 2 & 2 & 1 & 1 & 1 & 1 \\
\hline
\end{tabular}

${ }^{a}$ Including one harboring plasmid-mediated 16S rRNA methylase gene armA.

b Belonging to a single-locus variant of ST15.

${ }^{\mathrm{c}}$ Harboring plasmid-mediated 16S rRNA methylase gene armA and fosfomycin-resistance determinant fosA3.

bacteria, the status of use of those antimicrobials is not clear in companion animals. Moreover, reports on the detection of plasmid-mediated 16S rRNA methyltransferase genes conferring high-level resistance to various aminoglycosides and plasmid-mediated fosfomycin resistance genes were few in isolates from companion animals (Hou et al., 2012; Hidalgo et al., 2013). Our analysis revealed fosA3 in $2 \mathrm{E}$. coli isolates, and $\operatorname{armA}$ in a bla $a_{\mathrm{DHA}-1}$-harboring $K$. pneumoniae ST15 isolate for the first time in Japan. In addition, both fos $A 3$ and $\operatorname{arm} A$ were detected in a bla $a_{\mathrm{DHA}-1^{-}}$and bla $a_{\mathrm{SHV}-12}$-harboring $K$. pneumoniae ST37 isolate, which also showed resistance to colistin and tigecycline by disrupting $m g r B$ and $r a m R$ with IS1OR insertions (Taniguchi et al., 2017). The detection frequency of those resistance genes was low, but their transmission between companion animals and humans could become a significant future public health concern.

E. coli B2-non-O25b-ST1193, a newly emerging virulent and resistant lineage in China was noted in 5 isolates belonging to both UPEC and ExPEC (Wu et al., 2017). This lineage has phenotypic characteristics of fluoroquinolone resistance and lactose non-fermenting, and has been prevalent in human clinical isolates associated with urinary tract infection in Korea (Chang et al., 2014). Our study confirmed the

Table 4

Flanking genetic structures of $b l a_{\text {CTX-M }}$ genes.

\begin{tabular}{|c|c|c|c|c|}
\hline \multirow[t]{2}{*}{$b^{b l a} a_{\mathrm{CTX}-\mathrm{M}}$} & \multirow[t]{2}{*}{ Flanking genetic structures } & \multicolumn{2}{|c|}{ Origin (no. of animals) } & \multirow[t]{2}{*}{ Bacterial host (no. of isolates) } \\
\hline & & Dogs & Cats & \\
\hline \multirow[t]{4}{*}{$b l a_{\mathrm{CTX}-\mathrm{M}-27}$} & $\begin{array}{l}\text { IS26- } \Delta \mathrm{ISEcp} 1(208 \mathrm{bp})-b l a_{\mathrm{CTX}-\mathrm{M}-27}-\Delta \mathrm{IS} 903 D \\
\text { (391 bp)-IS26 }\end{array}$ & 9 & 1 & E. coli H30R/non-Rx (10) \\
\hline & $\begin{array}{l}\text { IS26- } \Delta \mathrm{ISEcp} 1(208 \mathrm{bp})-b l a_{\mathrm{CTX}-\mathrm{M}-27}-\Delta \mathrm{IS} 903 D \\
\text { (338 bp)-IS26 }\end{array}$ & 1 & & E. coli $H 30 \mathrm{R} / \mathrm{non}-\mathrm{Rx}(1)$ \\
\hline & $\begin{array}{l}\text { IS26- } \Delta \mathrm{ISEcp} 1(208 \mathrm{bp})-b l a_{\mathrm{CTX}-\mathrm{M}-27}-\Delta \mathrm{IS} 903 D \\
\text { (340bp)-IS26 }\end{array}$ & & 1 & E. coli $H 30 \mathrm{R} / \mathrm{non}-\mathrm{Rx}(1)$ \\
\hline & IS26- $\Delta \mathrm{ISEcp} 1(388 \mathrm{bp})-b l a_{\mathrm{CTX}-\mathrm{M}-27}-\mathrm{IS} 903 D$ & 2 & 1 & E. coli B2-ST1193 (2)/E. coli F (1) \\
\hline \multirow[t]{3}{*}{$b l a_{\mathrm{CTX}-\mathrm{M}-14}$} & ISEcp1-bla ${ }_{\mathrm{CTX}-\mathrm{M}-14-\mathrm{IS} 903}$ & 1 & 2 & E. coli H30R/non-Rx (1)/E. col non-O25b-ST131 (1)/E. coli B2-ST1262 (1) \\
\hline & ISEcp1-bla ${ }_{\mathrm{CTX}-\mathrm{M}-14-\mathrm{IS}}$ & 3 & & K. pneumoniae ST655 (3) \\
\hline & ISEcp1-bla ${ }_{\mathrm{CTX}-\mathrm{M}-14-\Delta \mathrm{IS} 903}$ & 6 & 1 & E. coli O25b-ST131-non-H30 (2)/E. coli D (4)/F (1) \\
\hline \multirow[t]{4}{*}{ bla $_{\mathrm{CTX}-\mathrm{M}-15}$} & ISEcp1-(48 bp)- bla $a_{\mathrm{CTX}-\mathrm{M}-15-o r f 477}$ & 13 & 3 & $\begin{array}{l}\text { E.coli H30R/Rx (2)/E. coli H30R-nonRx (2)/E. coli non-O25b-ST131 (1)/E. coli B2-ST127 } \\
\text { (1)/E. coli B2-ST1193 (1)/E. coli B2-ST38 (1)/E. coli F (2)/D (1) } \\
\text { K. pneumoniae ST4 (1)/ST15 (1)/ST45 (1)/ST307 (2) }\end{array}$ \\
\hline & ISEcp1-(48 bp)- bla $a_{\mathrm{CTX}-\mathrm{M}-15^{-}}$orf $477^{\mathrm{b}}$ & 1 & & E. $\operatorname{coli} \mathrm{F}(1)$ \\
\hline & ISEcp1- IS1-ISEcp1-(127 bp)-bla $a_{\mathrm{CTX}-\mathrm{M}-15-o r f 477}$ & & 1 & K. pneumoniae ST709 (1) \\
\hline & $\begin{array}{l}\text { IS } 26-\Delta \mathrm{ISEcp} 1(497 \mathrm{bp})-(48 \mathrm{bp})-b_{\mathrm{CTX}-\mathrm{M}-15^{-}} \\
\text {orf } 477\end{array}$ & & 2 & E. coli $H 30 \mathrm{R} / \mathrm{Rx}(1) / E$. coli Clade I or II (1) \\
\hline \multirow[t]{5}{*}{ bla $_{\mathrm{CTX}-\mathrm{M}-55}$} & ISEcp1-(45 bp)-bla ${ }_{\mathrm{CTX}-\mathrm{M}-55}-$ orf 477 & 2 & 3 & $\begin{array}{l}\text { E.coli B2-ST95 (1)/E. coli B1 (2) } \\
\text { K. pneumoniae ST15 (2) }\end{array}$ \\
\hline & ISEcp1-(48 bp)-bla $a_{\mathrm{CTX}-\mathrm{M}-55^{-o r f 477}}$ & 2 & 1 & E. coli $\mathrm{B} 2-\mathrm{ST} 1193(1) / E$. coli A(1)/F(1) \\
\hline & $\begin{array}{l}\text { IS26- } \triangle \mathrm{ISEcp} 1(497 \mathrm{bp})-(48 \mathrm{bp})-b l a_{\mathrm{CTX}-\mathrm{M}-55^{-}} \\
\text {orf } 477\end{array}$ & 1 & & E. coli $\mathrm{B} 1(1)$ \\
\hline & $\begin{array}{l}\text { IS26- } \Delta \mathrm{ISEcp} 1(242 \mathrm{bp})-(127 \mathrm{bp})-b l a_{\mathrm{CTX}-\mathrm{M}-55^{-}} \\
\text {orf } 477-\Delta b l a_{\mathrm{TEM}^{-}}-I S 26-f o s A 3\end{array}$ & 1 & & E. coli $\mathrm{F}(1)$ \\
\hline & $\begin{array}{l}\text { IS26- } \Delta \text { ISEcp1(242 bp)-(127 bp)-bla } a_{\text {CTX-M-55- }} \\
\text { orf } 477\end{array}$ & & 1 & E. coli $\mathrm{D}(1)$ \\
\hline \multirow[t]{4}{*}{$b l a_{\mathrm{CTX}-\mathrm{M}-2}$} & ISCR1- bla $a_{\mathrm{CTX}-\mathrm{M}-2^{2}}-\Delta o r f 3$ & & 1 & E. coli $\mathrm{B} 1(1)$ \\
\hline & ISCR1- $b l a_{\mathrm{CTX}-\mathrm{M}-2}$ & 6 & 4 & E. coli non-O25b-ST131 (1)/E. coli B1 (1)/C (1) \\
\hline & & & & K. pneumoniae ST11 (2)/ST15 (1)/ST709 (2) \\
\hline & & & & P. mirabilis (2) \\
\hline
\end{tabular}

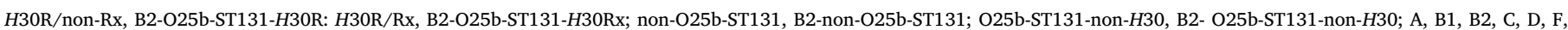
and Clade I or II, phylogroups A, B1, B2, C, D, F, and Clade I or II.

a Containing K156N in tnpA of IS903.

b Containing E271K in tnpA of ISEcp1. 
emergence of E. coli B2-non-O25b-ST1193 among companion animals.

Highly similar antimicrobial resistance genes and genotypes of $E$. coli including pandemic UPEC lineage ST131 or those of K. pneumoniae have been reported among companion animals and human (Harada et al., 2012, 2016). This study revealed the dominant prevalence of $E$. coli harboring bla $_{\mathrm{CTX}-\mathrm{M}-27}$ among pandemic lineage, B2-O25b-ST131H30R. This lineage also included $b l a_{\mathrm{CTX}-\mathrm{M}-15^{-}}, b l a_{\mathrm{CTX}-\mathrm{M}-3^{-}}$, and $b l a_{\mathrm{CTX}-\mathrm{M}-}$ 14 -encoding E. coli. Global widespread of ESBL-producing E. coli is associated with global clonal expansion of B2-O25b-ST131-H30R isolates harboring $b a_{\text {CTX-M-15 }}$ (Mathers et al., 2015). Instead, E. coli harboring bla $_{\mathrm{CTX-M-14}}$ combined with this lineage has been predominant in Japan (Matsumura et al., 2015). The bla $a_{\mathrm{CTX}-\mathrm{M}-27}$-carrying E. coli B2-O25bST131-H30R/non-Rx, which emerged in the early 2000s has become increasingly prevalent domestically in human, where Matsumura et al. have observed that the $b l a_{\mathrm{CTX}-\mathrm{M}-27}$ is confined to O25b-ST131-H30R/ non-Rx lineage (Matsumura et al., 2015). However, the $b l a_{\mathrm{CTX}-\mathrm{M}-27}$ was also detected among B2-non-O25-ST1193 (2 isolates) and F-non-O25 (1 isolate) though it was located within a rare flanking genetic structure,

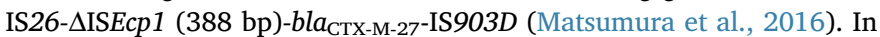
contrast, the surrounding genetic background of $b l a_{\mathrm{CTX}-\mathrm{M}-27}$ genes, IS26$\Delta \mathrm{ISEcp1-bla}$ CTX-M-27 $-\Delta \mathrm{IS} 903 \mathrm{D}$ (391 bp)-IS26 harbored by most $E$. coli B2-O25b-ST131-H30R/non-Rx in this study were identical to those harbored by human clinical isolates (Matsumura et al., 2015), suggesting circulation of $b_{\mathrm{CTX}-\mathrm{M}-27}$-encoding E. coli B2-O25b-ST131H30R/non-Rx lineage between human and companion animals in Japan. Analysis of the genetic environment of bla $a_{\text {CTX-м }}$ genes also allowed us to detect variation in the length of truncated IS903D, $338 \mathrm{bp}$ or $340 \mathrm{bp}$ in two isolates of this pandemic $E$. coli lineage, which was unique to canine and feline isolates. So, such unique flanking genetic structures may possibly be derived from external sources such as pet food or environmental pool of antimicrobial resistance genes and/or clones (Baede et al., 2017; Gomi et al., 2017). Because of the close contact not only with human but also with those external sources, companion animals may play an important role in prevalence dynamics of antimicrobial resistance genes including bla genes and/or high-risk clonal lineage that could cause human infections.

In conclusion, our results showed high prevalence of the $b l a_{\mathrm{CTX}-\mathrm{M}-27^{-}}$ harboring isolates among the pandemic E. coli B2-O25b-ST131-H30R/ non-Rx lineage. The genetic environment of $b a_{\mathrm{CTX}-\mathrm{M}-27}$ harbored by most of isolates of this lineage was identical to those harbored by human isolates, but flanking genetic structures unique to companion animals were also identified. Newly emerging virulent and resistant lineage B2-non-O25b-ST1193 was also confirmed in 5 isolates. The fosA 3 and/or armA genes were detected from $E$. coli and $K$. pneumoniae isolates. These data suggest that companion animals serve as a potential reservoir of antimicrobial resistant E. coli and $K$. pneumoniae. This also has considerable veterinary importance, since urinary tract infections are an important disease causing therapeutic challenges worldwide.

\section{Fundings}

This work was supported by the Research Grants for Medical Science from the Daiichi Sankyo Foundation (A16-1401, 2016) for bacteriological analyses including antimicrobial susceptibility testing. Molecular and genetic analyses of bacterial isolates from companion animals were supported by a Research Program on Emerging/Reemerging Infectious Disease of "Japan Agency for Medical Research and Development (AMED)”, grant control No.: 15fk0108007h0101.

\section{Conflict of interest statement}

None.

\section{Ethical approval}

Not required.

\section{Acknowledgements}

We are grateful to Kozue Oana, Shinshu University Graduate School of Medicine for scientific advice.

\section{Appendix A. Supplementary data}

Supplementary material related to this article can be found, in the online version, at doi: https://doi.org/10.1016/j.vetmic.2018.02.020.

\section{References}

Baede, V.O., Broens, E.M., Spaninks, M.P., Timmerman, A.J., Graveland, H., Wagenaar, J.A., Duim, B., Hordijk, J., 2017. Raw pet food as a risk factor for shedding of extended-spectrum beta-lactamase-producing Enterobacteriaceae in household cats. PLoS One 12, e0187239.

Bevan, E.R., Jones, A.M., Hawkey, P.M., 2017. Global epidemiology of CTX-M $\beta$-lactamases: temporal and geographical shifts in genotype. J. Antimicrob. Chemother. 72, 2145-2155.

Bortolaia, V., Hansen, K.H., Nielsen, C.A., Fritsche, T.R., Guardabassi, L., 2014. High diversity of plasmids harbouring bla $_{\mathrm{CMY}-2}$ among clinical Escherichia coli isolates from humans and companion animals in the upper Midwestern USA. J. Antimicrob. Chemother. 69, 1492-1496.

Chang, J., Yu, J., Lee, H., Ryu, H., Park, K., Park, Y.J., 2014. Prevalence and characteristics of lactose non-fermenting Escherichia coli in urinary isolates. J. Infect. Chemother. 20, 738-740.

Clermont, O., Lavollay, M., Vimont, S., Deschamps, C., Forestier, C., Branger, C., Denamur, E., Arlet, G., 2008. The CTX-M-15-producing Escherichia coli diffusing clone belongs to a highly virulent B2 phylogenetic subgroup. J. Antimicrob. Chemother. 61, 1024-1028.

Clermont, O., Christenson, J.K., Denamur, E., Gordon, D.M., 2013. The Clermont Escherichia coli phylotyping method revisited: improvement of specificity and detection of new phylo-groups. Environ. Microbiol. Rep. 5, 58-65.

Clinical and Laboratory Standards Institute (CLSI), 2015. Methods for dilution antimicrobial susceptibility tests for bacteria that grow aerobically; approved standard-tenth edition. CLSI Document M07-10. CLSI, Wayne, Pennsylvania, USA.

Clinical and Laboratory Standards Institute (CLSI), 2017. Performance standards for antimicrobial susceptibility testing: twenty-seventh informational supplement. CLSI Document M100-S27. CLSI, Wayne, Pennsylvania, USA.

Colpan, A., Johnston, B., Porter, S., Clabots, C., Anway, R., Thao, L., Kuskowski, M.A., Tchesnokova, V., Sokurenko, E.V., Johnson, J.R., VICTORY (Veterans Influence of Clonal Types on Resistance: Year 2011) Investigators, 2013. Escherichia coli sequence type 131 (ST131) as an emergent multidrug-resistant pathogen among U.S. veterans. Clin. Infect. Dis. 57, 1256-1265.

Dahbi, G., Mora, A., López, C., Alonso, M.P., Mamani, R., Marzoa, J., Coira, A., GarcíaGarrote, F., Pita, J.M., Velasco, D., Herrera, A., Viso, S., Blanco, J.E., Blanco, M., Blanco, J., 2013. Emergence of new variants of ST131 clonal group among extraintestinal pathogenic Escherichia coli producing extended-spectrum $\beta$-lactamases. Int. J. Antimicrob. Agents 42, 347-351.

Doi, Y., Arakawa, Y., 2007. 16S ribosomal RNA methylation: emerging resistance mechanism against aminoglycosides. Clin. Infect. Dis. 45, 88-94.

Donati, V., Feltrin, F., Hendriksen, R.S., Svendsen, C.A., Cordaro, G., García-Fernández, A., Lorenzetti, S., Lorenzetti, R., Battisti, A., Franco, A., 2014. Extended-spectrum- $\beta$ lactamases, AmpC $\beta$-lactamases and plasmid mediated quinolone resistance in Klebsiella spp. from companion animals in Italy. PLoS One 9, e90564.

European Committee on Antimicrobial Susceptibility Testing (EUCAST), 2017. Breakpoint Tables for Interpretation of MICs and Zone Diameters Version 7.0. valid from 2017-01-01. (12 February 2018, date last Accessed). http://www.eucast.org/ fileadmin/src/media/PDFs/EUCAST_files/Breakpoint_tables/v_7.0_Breakpoint_ Tables.pdf.

Ewers, C., Grobbel, M., Stamm, I., Kopp, P.A., Diehl, I., Semmler, T., Fruth, A., Beutlich, J., Guerra, B., Wieler, L.H., Guenther, S., 2010. Emergence of human pandemic O25:H4-ST131 CTX-M-15 extended-spectrum-ß-lactamase-producing Escherichia coli among companion animals. J. Antimicrob. Chemother. 65, 651-660.

Gomi, R., Matsuda, T., Matsumura, Y., Yamamoto, M., Tanaka, M., Ichiyama, S., Yoneda, M., 2017. Occurrence of clinically important lineages, including the sequence type 131 C1-M27 subclone, among extended-spectrum- $\beta$-lactamase-producing Escherichia coli in wastewater. Antimicrob. Agents Chemother. 61 pii: e00564-17.

Haenni, M., Ponsin, C., Métayer, V., Médaille, C., Madec, J.Y., 2012. Veterinary hospitalacquired infections in pets with a ciprofloxacin-resistant CTX-M-15-producing Klebsiella pneumoniae ST15 clone. J. Antimicrob. Chemother. 67, 770-771.

Harada, K., Nakai, Y., Kataoka, Y., 2012. Mechanisms of resistance to cephalosporin and emergence of O25b-ST131 clone harboring CTX-M-27 $\beta$-lactamase in extraintestinal pathogenic Escherichia coli from dogs and cats in Japan. Microbiol. Immunol. 56, 480-485.

Harada, K., Shimizu, T., Mukai, Y., Kuwajima, K., Sato, T., Usui, M., Tamura, Y., Kimura, Y., Miyamoto, T., Tsuyuki, Y., Ohki, A., Kataoka, Y., 2016. Phenotypic and molecular characterization of antimicrobial resistance in Klebsiella spp. isolates from companion animals in Japan: clonal dissemination of multidrug-resistant extended-spectrum $\beta$ lactamase-producing Klebsiella pneumoniae. Front. Microbiol. 7, 1021.

Hidalgo, L., Gutierrez, B., Ovejero, C.M., Carrilero, L., Matrat, S., Saba, C.K., SantosLopez, A., Thomas-Lopez, D., Hoefer, A., Suarez, M., Santurde, G., Martin-Espada, C., 
Gonzalez-Zorn, B., 2013. Klebsiella pneumoniae sequence type 11 from companion animals bearing ArmA methyltransferase, DHA-1 $\beta$-lactamase, and QnrB4. Antimicrob. Agents Chemother. 57, 4532-4534.

Hou, J., Huang, X., Deng, Y., He, L., Yang, T., Zeng, Z., Chen, Z., Liu, J.H., 2012. Dissemination of the fosfomycin resistance gene fosA 3 with CTX-M $\beta$-lactamase genes and $r m t B$ carried on IncFII plasmids among Escherichia coli isolates from pets in China. Antimicrob. Agents Chemother. 56, 2135-2138.

Johnson, J.R., Miller, S., Johnston, B., Clabots, C., Debroy, C., 2009. Sharing of Escherichia coli sequence type ST131 and other multidrug-resistant and urovirulent $E$. coli strains among dogs and cats within a household. J. Clin. Microbiol. 47, 3721-3725.

Johnson, J.R., Porter, S., Johnston, B., Kuskowski, M.A., Spurbeck, R.R., Mobley, H.L., Williamson, D.A., 2015. Host characteristics and bacterial traits predict experimental virulence for Escherichia coli bloodstream isolates from patients with urosepsis. Open Forum Infect. Dis. 2, ofv083.

Kawamura, K., Sugawara, T., Matsuo, N., Hayashi, K., Norizuki, C., Tamai, K., Kondo, T., Arakawa, Y., 2017. Spread of CTX-type extended-spectrum $\beta$-lactamase-producing Escherichia coli isolates of epidemic clone B2-O25-ST131 among dogs and cats in Japan. Microb. Drug Resist. 23, 1059-1066.

Li, Y., Li, Q., Du, Y., Jiang, X., Tang, J., Wang, J., Li, G., Jiang, Y., 2008. Prevalence of plasmid-mediated AmpC $\beta$-lactamases in a Chinese university hospital from 2003 to 2005: first report of CMY-2-type AmpC $\beta$-lactamase resistance in China. J. Clin. Microbiol. 46, 1317-1321.

Mathers, A.J., Peirano, G., Pitout, J.D., 2015. The role of epidemic resistance plasmids and international high-risk clones in the spread of multidrug-resistant Enterobacteriaceae. Clin. Microbiol. Rev. 28, 565-591.

Matsumura, Y., Johnson, J.R., Yamamoto, M., Nagao, M., Tanaka, M., Takakura, S., Ichiyama, S., Kyoto-Shiga Clinical Microbiology Study Group, Kyoto-Shiga Clinical Microbiology Study Group, 2015. CTX-M-27- and CTX-M-14-producing, ciprofloxacin-resistant Escherichia coli of the $H 30$ subclonal group within ST131 drive a Japanese regional ESBL epidemic. J. Antimicrob. Chemother. 70, 1639-1649.

Matsumura, Y., Pitout, J., Gomi, R., Matsuda, T., Noguchi, T., Yamamoto, M., Peirano, G., DeVinney, R., Bradford, P.A., Motyl, M.R., Tanaka, M., Nagao, M., Takakura, S., Ichiyama, S., 2016. Global Escherichia coli sequence type 131 clade with $b l a_{\mathrm{CTX}-\mathrm{M}-27}$ gene. Emerg. Infect. Dis. 22, 1900-1907.

Nagano, Y., Nagano, N., Wachino, J., Ishikawa, K., Arakawa, Y., 2009. Novel chimeric $\beta$ lactamase CTX-M-64, a hybrid of CTX-M-15-Like and CTX-M-14 $\beta$-lactamases, found in a Shigella sonnei strain resistant to various oxyimino-cephalosporins, including ceftazidime. Antimicrob. Agents Chemother. 53, 69-74.

Okubo, T., Sato, T., Yokota, S., Usui, M., Tamura, Y., 2014. Comparison of broad-spectrum cephalosporin-resistant Escherichia coli isolated from dogs and humans in Hokkaido, Japan. J. Infect. Chemother. 20, 243-249.

Peirano, G., Richardson, D., Nigrin, J., McGeer, A., Loo, V., Toye, B., Alfa, M., Pienaar, C., Kibsey, P., Pitout, J.D., 2010. High prevalence of ST131 isolates producing CTX-M-15 and CTX-M-14 among extended-spectrum- $\beta$-lactamase-producing Escherichia coli isolates from Canada. Antimicrob. Agents Chemother. 54, 1327-1330.

Perez-Perez, F.J., Hanson, N.D., 2002. Detection of plasmid-mediated AmpC $\beta$-lactamase genes in clinical isolates by using multiplex PCR. J. Clin. Microbiol. 40, 2153-2162.

Price, L.B., Johnson, J.R., Aziz, M., Clabots, C., Johnston, B., Tchesnokova, V., Nordstrom, L., Billig, M., Chattopadhyay, S., Stegger, M., Andersen, P.S., Pearson, T., Riddell, K., Rogers, P., Scholes, D., Kahl, B., Keim, P., Sokurenko, E.V., 2013. The epidemic of extended-spectrum- $\beta$-lactamase-producing Escherichia coli ST131 is driven by a single highly pathogenic subclone, H30-Rx. MBio 4, e00377-13.

Suzuki, S., Shibata, N., Yamane, K., Wachino, J., Ito, K., Arakawa, Y., 2009. Change in the prevalence of extended-spectrum- $\beta$-lactamase-producing Escherichia coli in Japan by clonal spread. J. Antimicrob. Chemother. 63, 72-79.

Taniguchi, Y., Maeyama, Y., Ohsaki, Y., Hayashi, W., Osaka, S., Koide, S., Tamai, K., Nagano, Y., Arakawa, Y., Nagano, N., 2017. Co-resistance to colistin and tigecycline by disrupting $m g r B$ and $\operatorname{ramR}$ with IS insertions in a canine Klebsiella pneumoniae ST37 isolate producing SHV-12, DHA-1 and FosA3. Int. J. Antimicrob. Agents 50, 697-698.

Wachino, J., Yamane, K., Suzuki, S., Kimura, K., Arakawa, Y., 2010. Prevalence of fosfomycin resistance among CTX-M-producing Escherichia coli clinical isolates in Japan and identification of novel plasmid-mediated fosfomycin-modifying enzymes. Antimicrob. Agents Chemother. 54, 2061-2064.

Wohlwend, N., Endimiani, A., Francey, T., Perreten, V., 2015. Third-generation-cephalosporin-resistant Klebsiella pneumoniae isolates from humans and companion animals in Switzerland: spread of a DHA-producing sequence type 11 clone in a veterinary setting. Antimicrob. Agents Chemother. 59, 2949-2955.

Wu, J., Lan, F., Lu, Y., He, Q., Li, B., 2017. Molecular characteristics of ST1193 clone among phylogenetic group B2 non-ST131 fluoroquinolone-resistant Escherichia coli. Front. Microbiol. 8, 2294.

Zhao, W.H., Hu, Z.Q., 2013. Epidemiology and genetics of CTX-M extended-spectrum $\beta$ lactamases in Gram-negative bacteria. Crit. Rev. Microbiol. 39, 79-101. 
Table S1. Primers for sequencing of ESBL and pAmpC genes

\begin{tabular}{|c|c|c|c|c|}
\hline Gene & & Primers $^{\text {a }}$ (5' to $\left.3^{\prime}\right)$ & $\begin{array}{l}\text { Annealing } \\
\text { temperature }\end{array}$ & $\begin{array}{l}\text { Amplicon size } \\
\text { (bp) }\end{array}$ \\
\hline \multirow[t]{2}{*}{$b l a_{\mathrm{CTX}-\mathrm{M}-1}$} & $\mathrm{Fw}$ & CTTCCAGAATAAGGAATC & \multirow{14}{*}{$55^{\circ} \mathrm{C}$} & \multirow{2}{*}{908 bp } \\
\hline & Rev & CCGTTTCCGCTATTACAA & & \\
\hline \multirow[t]{2}{*}{$b l a_{\mathrm{CTX}-\mathrm{M}-2}$} & $\mathrm{Fw}$ & TTAATGATGACTCAGAGCATTC & & \multirow{2}{*}{902 bp } \\
\hline & Rev & GATACCTCGCTCCATTTATTG & & \\
\hline \multirow[t]{2}{*}{$b l a_{\text {СТХ-м-9 }}$} & $\mathrm{Fw}$ & CTGATGTAACACGGATTGAC & & \multirow{2}{*}{913 bp } \\
\hline & Rev & TTACAGCCCTTCGGCGATGA & & \\
\hline \multirow[t]{2}{*}{$b l a \mathrm{TEM}$} & $\mathrm{Fw}$ & ATAAAATTCTTGAAGACGAAA & & \multirow{2}{*}{$1080 \mathrm{bp}$} \\
\hline & Rev & GACAGTTACCAATGCTTAATCA & & \\
\hline \multirow[t]{2}{*}{$b l a_{\mathrm{SHV}}$} & $\mathrm{Fw}$ & ATTTGTCG CTTCTTTACTCGC & & \multirow{2}{*}{$1051 \mathrm{bp}$} \\
\hline & Rev & TTTATGGCGTTACCTTTGACC & & \\
\hline \multirow[t]{2}{*}{$b l a_{\mathrm{CMY}-2}$} & Fw & ATGATGAAAAAATCGTTATGCT & & \multirow{2}{*}{562 bp } \\
\hline & Rev & TTATTGCAGCTTTTCAAGAATGCG & & \\
\hline \multirow{2}{*}{$b l a_{\mathrm{DHA}-1}$} & $\mathrm{Fw}$ & CACGGAAGGTTAATTCTGATG & & \multirow{2}{*}{$1167 \mathrm{bp}$} \\
\hline & Rev & GGAAAAAAATTATTCCAGTGC & & \\
\hline
\end{tabular}

${ }^{\mathrm{a}} \mathrm{Fw}$, forward primer; Rev; reverse primer. 
Table S2. Primers used for analyzing flanking genetic structures of $b l_{\mathrm{CTX}-\mathrm{M}}$ genes

\begin{tabular}{|c|c|c|}
\hline PCR target & Primer name & Sequence (5' to 3') \\
\hline \multirow{2}{*}{ ISEcpl } & ISEcpl-F & GCAGGTCTTTTTCTGCTCCTTG \\
\hline & $\operatorname{tnp} A$ ISEcpl-F & TCTCGCGTACTGAAACCAGA \\
\hline \multirow{3}{*}{ IS26 } & IS26-F & AACGCGGAGTGAATGTCGAT \\
\hline & $\operatorname{tnp} A$ IS $26-\mathrm{F}$ & CTGCTTACCAGGCGCATTTC \\
\hline & IS26-R & GGAAGGGTTACGCCAGTACC \\
\hline ISCRI & ISCRl-F & CCGGTTACACCAAAGCCTCT \\
\hline \multirow{2}{*}{ IS903 } & IS903-R & CGCAACCTGACCATCGTA \\
\hline & $\Delta \mathrm{IS} 903-\mathrm{R}$ & CATCATCCAGCCAGAAAGTT \\
\hline fos $A 3$ & fos $A 3-\mathrm{R}$ & TCAATCAAAAAAGACCATC \\
\hline \multirow{2}{*}{ Orf477 } & Orf477-R & AAACCTGTACGGTGCTGGAG \\
\hline & Orf477 (inner)-R & CCGTACAGGTTTCCCCCAAT \\
\hline TEM & TEM-R & CAGTGCTGCAATGATACCGC \\
\hline Orf3 & Orf3-R & ATCGAACTCGAGCGTTGACA \\
\hline \multirow{2}{*}{$b l a_{\mathrm{CTX}-\mathrm{M}-1}$} & CTX-M-1 (inner)-F & GCTGTTGTTAGGAAGTGTGC \\
\hline & CTX-M-1 (inner)-R & CCATTGCCCGAGGTGAAG \\
\hline \multirow{2}{*}{$b l a_{\mathrm{CTX}-\mathrm{M}-2}$} & CTX-M-2 (inner)-F & TTTGCGATGTGCAGTACCAGTAA \\
\hline & CTX-M-2 (inner)-R & AAATAGCAGGGGTAGCGTCG \\
\hline \multirow{2}{*}{$b l a_{\text {СТХ-М-9 }}$} & CTX-M-9 (inner)-F & ACCTATTTTACCCAGCCGCA \\
\hline & CTX-M-9 (inner)-R & CACTCGTCTGCGCATAAAGC \\
\hline
\end{tabular}


Table S3. Characteristics of ESBL- and/or pAmpC-producing E. coli and K. pneumoniae isolates from companion animals

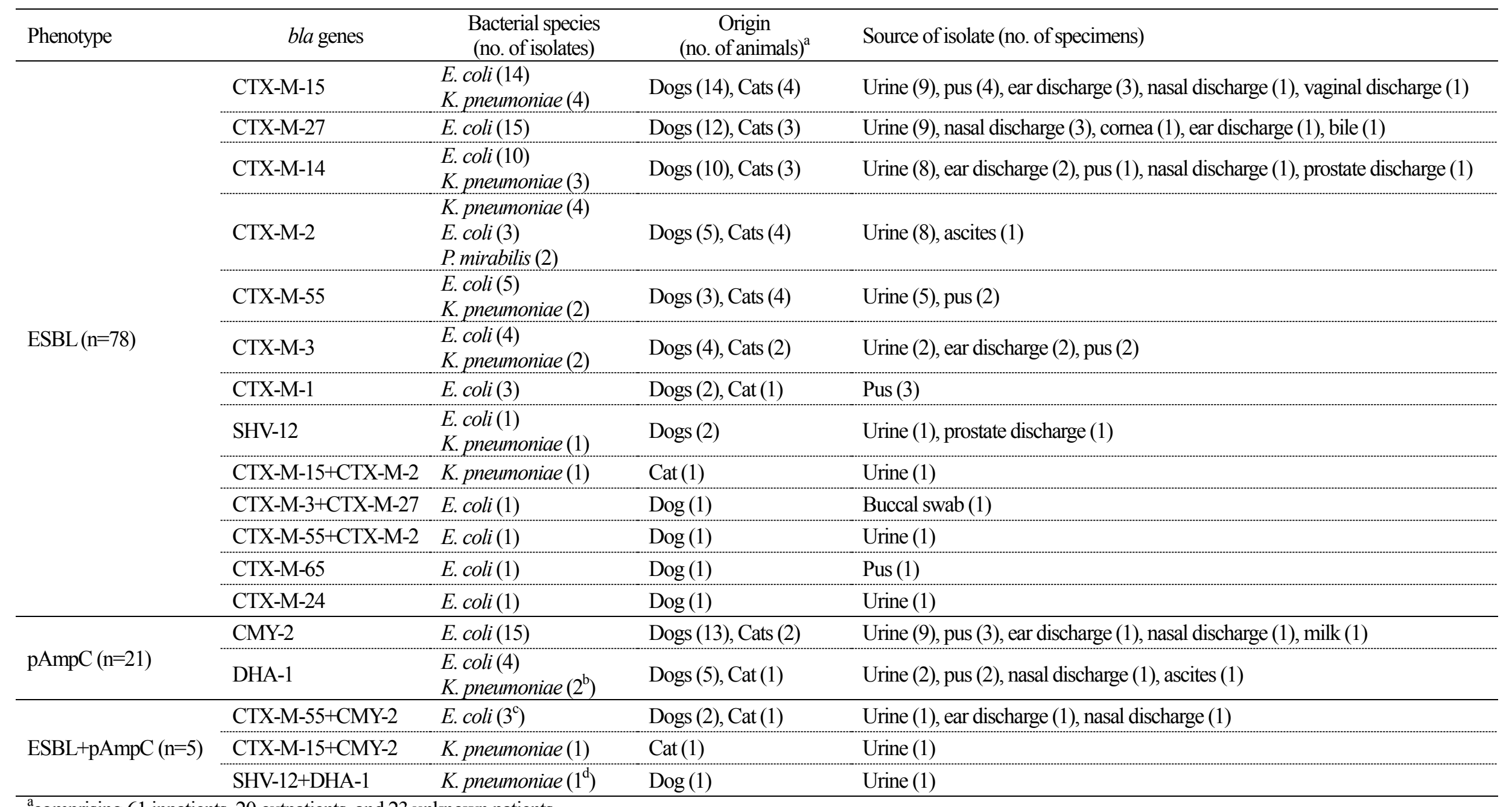

acomprising 61 inpatients, 20 outpatients, and 23 unknown patients

bincluding one harboring plasmid-mediated $16 \mathrm{~S}$ rRNA methylase gene arm $A$

including one harboring plasmid-mediated fosfomycin-resistance determinant fos $A 3$

dharboring plasmid-mediated $16 \mathrm{~S}$ rRNA methylase gene $\operatorname{arm} A$ and fosfomycin-resistance determinant fos $A 3$ 
Table S4. MIC ranges and MIC 90 values of antimicrobial agents for the third-generation cephalosporin-resistant Escherichia coli and Klebsiella pneumoniae isolated from companion animals

\begin{tabular}{|c|c|c|c|c|c|c|c|c|c|}
\hline \multirow{3}{*}{ Antimicrobials } & \multicolumn{4}{|c|}{ ESBL producers } & \multicolumn{3}{|c|}{ pAmpC producers } & \multicolumn{2}{|c|}{$\mathrm{ESBL}+\mathrm{pAmpC}$ producers } \\
\hline & \multicolumn{2}{|c|}{ E. $\operatorname{coli}(\mathrm{n}=59)$} & \multicolumn{2}{|c|}{ K. pneumoniae $(\mathrm{n}=17)$} & \multicolumn{2}{|c|}{ E. $\operatorname{coli}(\mathrm{n}=19)$} & \multirow{2}{*}{$\begin{array}{c}\text { K. pneumoniae }(\mathrm{n}=2) \\
\text { MIC range } \\
(\mathrm{mg} / \mathrm{L})\end{array}$} & \multirow{2}{*}{$\begin{array}{c}\text { E. } \operatorname{coli}(\mathrm{n}=3) \\
\text { MIC range }(\mathrm{mg} / \mathrm{L})\end{array}$} & \multirow{2}{*}{$\begin{array}{c}\text { K. pneumoniae }(\mathrm{n}=2) \\
\text { MIC range }(\mathrm{mg} / \mathrm{L})\end{array}$} \\
\hline & $\begin{array}{c}\text { MIC range } \\
(\mathrm{mg} / \mathrm{L})\end{array}$ & $\begin{array}{l}\mathrm{MIC}_{90} \\
(\mathrm{mg} / \mathrm{L})\end{array}$ & $\begin{array}{c}\text { MIC range } \\
(\mathrm{mg} / \mathrm{L})\end{array}$ & $\begin{array}{l}\mathrm{MIC}_{90} \\
(\mathrm{mg} / \mathrm{L})\end{array}$ & $\begin{array}{c}\text { MIC range } \\
(\mathrm{mg} / \mathrm{L})\end{array}$ & $\begin{array}{l}\mathrm{MIC}_{90} \\
(\mathrm{mg} / \mathrm{L})\end{array}$ & & & \\
\hline piperacillin & $>64$ & $>64$ & $>64$ & $>64$ & $\leq 16->64$ & $>64$ & $>64$ & $>64$ & $>64$ \\
\hline piperacillin/tazobactam & $\leq 16->64$ & $\leq 16$ & $\leq 16->64$ & $\leq 16$ & $\leq 16->64$ & $\leq 16$ & $\leq 16$ & $\leq 16$ & 64 \\
\hline cefpodoxime & $>4$ & $>4$ & $>4$ & $>4$ & $>4$ & $>4$ & $>4$ & $>4$ & $>4$ \\
\hline ceftazidime & $\leq 4->8$ & $>8$ & $\leq 4->8$ & $>8$ & $\leq 4->8$ & $>8$ & $>8$ & $>8$ & $>8$ \\
\hline cefotaxime & $>2$ & $>2$ & $>2$ & $>2$ & $2->2$ & $>2$ & $>2$ & $>2$ & $>2$ \\
\hline cefepime & $\leq 8->16$ & $>16$ & $\leq 8->16$ & $>16$ & $\leq 8$ & $\leq 8$ & $\leq 8$ & $>16$ & $\leq 8->16$ \\
\hline cefpirome & $\leq 8->16$ & $>16$ & $16->16$ & $>16$ & $\leq 8$ & $\leq 8$ & $\leq 8$ & $>16$ & $16->16$ \\
\hline cefmetazole & $\leq 16$ & $\leq 16$ & $\leq 16$ & $\leq 16$ & $\leq 16->32$ & $>32$ & $>32$ & $\leq 16->32$ & $32->32$ \\
\hline aztreonam & $\leq 4->8$ & $>8$ & $\leq 4->8$ & $>8$ & $\leq 4->8$ & $>8$ & 8 & $>8$ & $>8$ \\
\hline imipenem & $\leq 1$ & $\leq 1$ & $\leq 1$ & $\leq 1$ & $\leq 1$ & $\leq 1$ & $\leq 1$ & $\leq 1$ & $\leq 1$ \\
\hline meropenem & $\leq 1$ & $\leq 1$ & $\leq 1$ & $\leq 1$ & $\leq 1$ & $\leq 1$ & $\leq 1$ & $\leq 1$ & $\leq 1$ \\
\hline gentamicin & $\leq 4->8$ & $>8$ & $\leq 4->8$ & $>8$ & $\leq 4->8$ & $>8$ & $\leq 4->8$ & $\leq 4$ & $\leq 4->8$ \\
\hline amikacin & $\leq 16$ & $\leq 16$ & $\leq 16$ & $\leq 16$ & $\leq 16$ & $\leq 16$ & $\leq 16->32$ & $\leq 16$ & $\leq 16->32$ \\
\hline levofloxacin & $\leq 2->4$ & $>4$ & $\leq 2->4$ & $>4$ & $\leq 2->4$ & $>4$ & $>4$ & $>4$ & $>4$ \\
\hline fosfomycin & $\leq 4->16$ & $\leq 4$ & $\leq 4->16$ & $>16$ & $\leq 4->16$ & $\leq 4$ & 16 & $\leq 4->16$ & $>16$ \\
\hline colistin & $\leq 2$ & $\leq 2$ & $\leq 2$ & $\leq 2$ & $\leq 2$ & $\leq 2$ & $\leq 2$ & $\leq 2$ & $\leq 2->2$ \\
\hline
\end{tabular}

